\title{
Comunicação e consumo: discussões para a compreensão de práticas e sentidos em construção no ambiente contemporâneo
}

Valdenise Leziér Martyniuk

ROCHA, R. M.; CASAQUI, V. (orgs.).

Estéticas Midiáticas e

Narrativas do Consumo.

Porto Alegre, Sulina, 2012. 279 p.

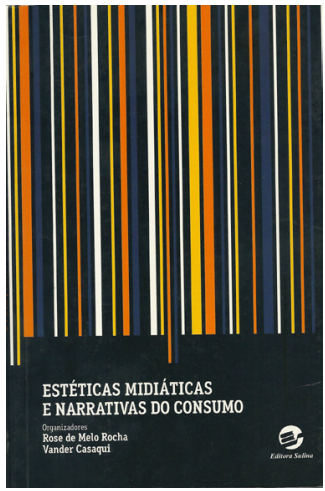

Resumo: O livro traz uma coletânea de artigos de pesquisadores em comunicação, que abordam as relações entre comunicação e os fenômenos do consumo. As temáticas da imagem, do imaginário, da subjetividade, do entretenimento, da ética e da educação, presentes em diversas manifestações midiáticas, são analisadas, percorrendo um amplo espectro de possibilidades de investigação, ancoradas em proposições de teóricos da comunicação e da semiótica.

Palavras-chaves: comunicação; consumo; mídias; narrativas. 
Abstract: Communications and consumption: discussions for an understanding of practices and meanings under construction in the contemporary environment - The book Estéticas Midiáticas e Narrativas do Consumo [Mediatic Aesthetics and Consumption Narratives] comprises a collection of papers by communications researchers that discuss the relationships between communications and the phenomena of consumption. Based on propositions by theorists of communications and semiotics, an analysis is made of themes such as image, imaginary, subjectivity, entertainment, ethics and education, which are present in many media manifestations, covering a broad spectrum of research possibilities.

Keywords: communications; consumption; media; narratives.

Fruto de pesquisas diversas, apresentadas e discutidas em evento acadêmico, o livro permite navegar por debates que residem no campo das "intersecções entre comunicação e consumo", conforme apresentam seus organizadores Rose de Melo Rocha eVander Casaqui (p. 7), percebendo a efervescência de seus desdobramentos na sociedade contemporânea. Como é seu papel, os pesquisadores, reunidos na edição, formulam questões importantes para compreender o cenário atual e suas perspectivas, bem como buscam caminhos metodológicos de análise, crítica e multiplicação de conhecimento.

Em um terreno cujas estradas estão ainda por pavimentar, é justamente a descrição da atividade de investigação que suscita no outro a curiosidade por elucidar tais desafios. Em vez de ditar regras sobre o funcionamento do novo mercado e de dizer como se comunicar nesse ambiente, as questões levam os leitores (os quais supomos que devam ser na maioria estudantes da área de comunicação e consumo) à reflexão. Os textos apresentados promovem novos olhares dirigidos às diferentes manifestações midiáticas, seja pela abordagem teórica que Ihes propõem, seja por entenderem que os estereótipos que recobrem certos grupos e objetos precisam ser questionados.

Algumas das reflexões dos artigos parecem ser mais aprofundadas que outras, o que pode ser atribuído a diversas causas. Evidentemente não haveria padronização entre as análises, dado que as manifestações observadas são muito variadas nessa complexa rede de movimentações culturais implicadas nas relações do consumo, fato que só enriquece a publicação, chamando a atenção do enunciatário para a emergência das discussões em pauta. Além disso, as pesquisas dos autores estão em diferentes estágios, o que justifica a colocação de textos bastante claros e maduros ao lado de outros ainda parciais, na etapa de apresentação de problemas e objetos. Igual valor aqui se atribui a uma obra que não pretende ser um desfecho, mas uma dinamizadora de polêmica, incitar o pensamento à análise do fenômeno do consumo, sem se adiantar em críticas cristalizadas ou euforias igualmente sólidas, uma vez que a sociedade líquida da qual se fala esquenta e entra em ebulição no calor do debate.

Na discussão sobre estética, imagem e imaginário, visibilidade e visualidade, os valores promovidos no consumo são confrontados e postos em análise referendada 
por pensadores latino-americanos (especialmente MARTíN-BARBERO, 2003 e CANCLINI, 2005), bem como de outras origens (FLUSSER, 2007; DEBORD, 2000 e outros) abordagens férteis e reveladoras de uma sociedade que se faz no local, mas dialoga com o global e vive na e pela visibilidade. O espetáculo torna visíveis indivíduos, corporações e suas marcas, artistas e suas obras. Arte e publicidade se encontram em dois dos textos seguintes. As fronteiras entre seus campos se tornam nebulosas, um interpenetrando o outro. Tal ponto nevrálgico pode ser vinculado ao debate ético entre produção de conteúdo editorial e publicitário, em evidência nas mídias, fato que corrobora a possibilidade de uma leitura que fomente outras pesquisas.

O indivíduo e sua imagem, na análise dos corpos publicizados, faz ponte com as pesquisas sobre os manuais de autoajuda e a realização profissional euforizada nos reality shows, que premiam com louros os bem-sucedidos, numa corrida desenfreada por ocupar lugares de destaque social. Mais que um emprego ou conquista pessoal, o ganho se dá pela visibilidade e pela fama, ainda que temporárias, das pequenas vitórias obtidas a cada capítulo. Modelagens sugeridas nessas análises poderiam ser úteis para outras manifestações midiáticas de igual teor: quem perde mais peso, quem conquista o candidato ao namoro, quem aprende a se vestir elegantemente, quem é o melhor novo chef de cozinha, qual a cirurgia plástica melhor sucedida, dentre tantos outros testes de superação, motes do entretenimento.

O lado corporativo da relação de consumo é observado com igual rigor, tanto entendendo seu poder econômico, quanto compreendendo que um novo consumidor desafia as práticas tradicionais de convencimento e persuasão. Novas abordagens, que privilegiam a experiência, a sensibilidade, o ajustamento (parafraseando LANDOWSKI, 2006 - autor também citado na obra), fazem-se ver na disputa por um consumidor-fã nas redes sociais.

O mesmo texto dialoga, por exemplo, com o questionamento sobre os critérios de classificação em camadas sociais vigentes no Brasil e em outros países, que embora sejam úteis, deixam brechas e não são comparáveis entre si, por utilizarem parâmetros distintos e não necessariamente correspondentes aos perfis dos estratos sociais. A criança, enquanto público e consumidor, constitui tema de pesquisa, em que o leitor poderá encontrar a rejeição a um simulacro de infante hipossuficiente (usando o termo do Conar - Conselho Nacional de Autorregulamentação Publicitária), considerando as ambiguidades do tratamento a esse sujeito por parte de seus familiares, amigos e de agentes do ambiente escolar. Não necessariamente a criança da qual se fala é uma pessoa autônoma e independente, mas também não absolutamente receptiva e submissa, como fazem crer alguns discursos.

Tratamento similar é dado em outra análise do consumidor, que, na definição primeira do modelo de processo de comunicação, quando adaptado às leituras das práticas mercadológicas, especialmente em função do fenômeno das mídias de massa, é submetido ao papel de receptor passivo, subserviente até. Sob o olhar desse artigo, 
o consumidor é reconhecido como crítico, respondente, ativo e mesmo produtor de conteúdo de comunicação, dotado de habilidade, conhecimento e técnica para exercer tal função, sustentada pelo acesso à tecnologia.

Não se pode dizer que a lista desses objetos esgote as manifestações do momento atual do consumo. Talvez muitos outros temas relevantes ainda por discutir estejam ausentes. Mas, diante de uma seleção feita a partir de exposições de um evento, é notório que o conjunto de temáticas aqui reunidas permita desvendar estratégias das empresas interessadas no consumo (marcas comerciais) cujas artimanhas de comunicação são esmiuçadas. Assim, no todo do trabalho, é possível compreender como os estereótipos cristalizados na sociedade emergem na enunciação publicitária em diversas mídias que, apesar de inseridas em uma discussão sobre o novo, continuam a reproduzir padrões de posse, aparência e comportamento. Ainda, as mídias de nova geração ganham espaço nas análises, pois são motores de desenvolvimento da sociedade no momento. Todas essas relações são postas em evidência desde o título, que menciona as "narrativas do consumo", demonstrando passar pela construção de histórias vividas por sujeitos. Por isso o livro se apoia à ideia de que marcas e consumidores atuam na sociedade como identidades em contato e contágio, mediados ou não, o que reafirma a importância da estética nas expressões das mídias e dos próprios indivíduos, em seus corpos e atitudes. Conforme apresentam os organizadores, "o consumo é essencialmente uma mediação social fundada em processos comunicacionais" (p. 8).

Não é necessário um roteiro de leitura. Partindo do prefácio de Prado (2013) e da apresentação de Rose de Melo Rocha, o leitor já degusta pitadas do que estará por vir, e poderá, de acordo com seu interesse, buscar as pesquisas relacionadas aos seus próprios estudos, selecionando os objetos que mais lhe interessem, bem como observando ideias de autores contemporâneos que perpassam vários dos artigos.

As questões abordadas estão em pauta na maioria das escolas de comunicação, tais como aquelas que tematizam a sociedade em rede (CASTELLS, 2002), a superficialidade das relações na modernidade líquida (BAUMAN, 2001), a ênfase no valor do novo (e por consequência, a evidência de efemeridades) e o consumo como partícipe da vida social (SEMPRINI, 2006). Ao mesmo tempo, o modo como o debate se organiza na publicação, ela mesma em relação intertextual com o evento que a gerou e em formação de rede entre os textos dentro do livro, já configura, na forma, o modelo de relacionamento social da atualidade. Intercâmbios entre áreas do conhecimento são manifestos em grande parte dos artigos. Útil para estudantes e pesquisadores, não apresenta teorias. Em vez disso, as aplica devidamente em investigações que se interessam pelas minúcias do consumo e da comunicação e metonimicamente dão a ver a cena contemporânea dentro de um todo complexo de relações. 
Valdenise Leziér Martyniuk é doutora em Comunicação e Semiótica, docente dos cursos de Administração, Publicidade e Propaganda e MBA em Marketing da PUCSP, professora do curso de pós-graduação em Marketing do Senac/SP e pesquisadora do Centro de Pesquisas Sociossemióticas.

valdenise@pucsp.br

\section{Referências}

BAUMAN, Z. Modernidade líquida. Rio de janeiro: Jorge Zahar Editor, 2001.

CANCLINI, N. G. Consumidores e cidadãos. Rio de Janeiro: Editora UFRJ, 2005.

CASTELLS, M. A sociedade em rede. Rio de Janeiro: Paz e Terra, 2002.

DEBORD, Guy. A sociedade do espetáculo. Rio de Janeiro: Contraponto, 2000.

FLUSSER, V. O mundo codificado. São Paulo: Cosac Naify, 2007.

LANDOWSKI, E. Les intéractions risquées. Limoges: Pulin, 2006.

MARTÍN-BARBERO, J. Dos meios à mediações. Rio de Janeiro: Editora UFRJ, 2003.

PRADO, J. L. A. Convocações biopolíticas dos dispositivos comunicacionais. São Paulo: Educ/ Fapesp, 2013.

SEMPRINI, A. A marca pós-moderna - poder e fragilidade da marca na sociedade contemporânea. São Paulo: Estação das Letras e Cores, 2006. 